\title{
A FURTHER GENERALIZATION OF ACZÉL'S INEQUALITY AND POPOVICIU'S INEQUALITY
}

\author{
SHANHE WU
}

Abstract. In this paper, a new generalization of Aczél's inequality is established, which contains as special case a sharpened version of Popoviciu's inequality:

$$
\left(a_{1}^{p}-\sum_{i=2}^{n} a_{i}^{p}\right)^{\frac{1}{p}}\left(b_{1}^{q}-\sum_{i=2}^{n} b_{i}^{q}\right)^{\frac{1}{q}} \leqslant a_{1} b_{1}-\left(\sum_{i=2}^{n} a_{i} b_{i}\right)-\frac{a_{1} b_{1}}{\max \{p, q\}}\left(\sum_{i=2}^{n}\left(\frac{a_{i}^{p}}{a_{1}^{p}}-\frac{b_{i}^{q}}{b_{1}^{q}}\right)\right)^{2}
$$

where $p, q, a_{i}, b_{i}(i=1,2, \cdots, n)$ are positive numbers, $p^{-1}+q^{-1}=1, a_{1}^{p}-\sum_{i=2}^{n} a_{i}^{p}>0$ and $b_{1}^{q}-\sum_{i=2}^{n} b_{l}^{q}>0$. Moreover, an integral inequality of Aczél-Popoviciu type is given.

Mathematics subject classification (2000): 26D15, 26D20.

Key words and phrases: Aczél's inequality, Popoviciu's inequality, generalized Hölder's inequality, Bernoulli's inequality, generalization, sharpen.

\section{REFERENCES}

[1] J. AcZÉL, Some general methods in the theory of functional equations in one variable, New applications of functional equations, Uspehi. Mat. Nauk (N.S.), 11, 69, (3) (1956), 3-68 (in Russian).

[2] Y. J. CHO, M. MATIĆ AND J. PEČARIĆ, Improvements of some inequalities of Aczél's type, J. Math. Anal. Appl., 259, (2001), 226-240 .

[3] X. H. Sun, Aczél-Chebyshev type inequality for positive linear functions, J. Math. Anal. Appl., 245, (2000), 393-403.

[4] L. Losonczi, Z. PÁles, Inequalities for indefinite forms, J. Math. Anal. Appl., 205, (1997), 148-156.

[5] A. M. MERCER, Extensions of Popoviciu's inequality using a general method, J. Inequal. Pure Appl. Math., 4, (1) (2003), Article 11.

[6] V. Mascioni, A note on Aczél type inequalities, J. Inequal. Pure Appl. Math., 3, (5) (2002), Article 69.

[7] S. S. Dragomir, B. Mond, Some inequalities of Aczél type for gramians in inner product spaces, Nonlinear Funct. Anal. Appl., 6, (2001), 411-424.

[8] R. Bellman, On an inequality concerning an indefinite form, Amer. Math. Monthly., 63, (1956), 108-109.

[9] P. M. VASIĆ, J. E. PeČARIĆ, On the Jensen inequality for monotone functions, An. Univ. Timisoara. Ser. St. Mathematice, 17, (1) (1979), 95-104.

[10] J. C. KUANG, Applied Inequalities, second ed., Hunan Education Press, Changsha, China, 1993, 180-181 (in Chinese).

[11] D. S. Mitrinović, J. E. PeČARIĆ AND A. M. FInK, Classical and New Inequalities in Analysis, Kluwer Academic Publishers, Dordrecht, 1993, 117-120.

[12] T. Popoviciu, On an inequality, Gaz. Mat. Fiz. Ser. A, 11, (64) (1959), 451-461 (in Romanian).

[13] S. Wu, L. Debnath, Generalizations of Aczel's inequality and Popoviciu's inequality, Indian J. Pure Appl. Math., 36, (2) (2005), 49-62. 
[14] S. Wu, L. DeBNATH, A new generalization of Aczél's inequality and its applications to the improvement of Bellman's inequality, J. Math. Anal. Appl., (2007), to appear.

[15] Z. PÁLES, On Hölder-type inequalities, J. Math. Anal. Appl., 95, (1983), 457-466.

[16] D. S. Mitrinović, P. M. VAsIĆ, Analytic Inequalities, Springer-Verlag, New York, 1970, 34-35. 